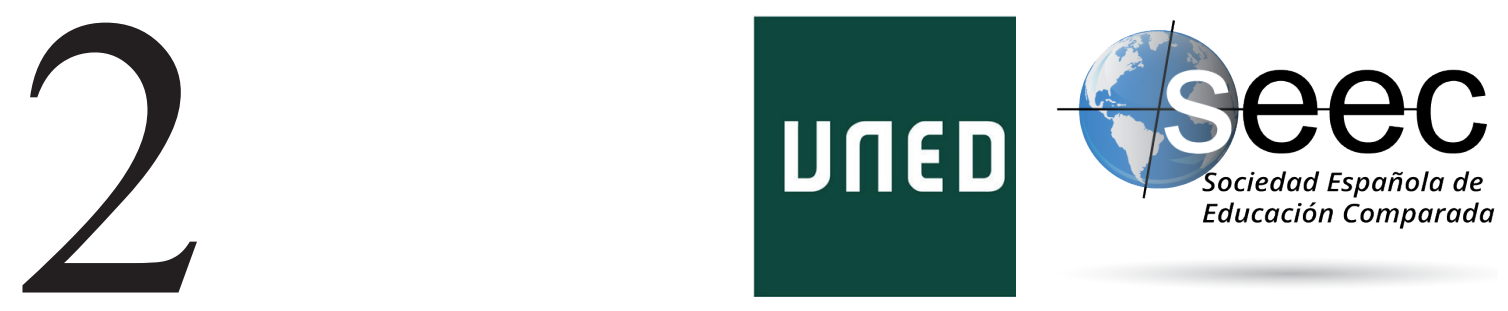

\title{
Comparative Education and Empires*
}

Educación comparada e imperios

Robert Cowen**

DOI: $10.5944 /$ reec.31.2018.21828

\section{Recibido: 15 de marzo de 2018 Aceptado: 9 de mayo de 2018}

\footnotetext{
* Acknowledgement: I wish, along with my colleague Leslie Bash, to acknowledge the influence of our distinguished former colleague Professor Jagdish Gundara on our interest in Empires. Jagdish himself, a Sikh, brought up in Kenya, later studied in McGill University and in Edinburgh University and he worked in the University of London and more recently in University College, London -all universities with a history that linked with Empire. Jagdish helped to educate us. He had been going to write for this volume: his own interests in multicultural and intercultural education overlapped with past and present versions of 'empire' - cultural, political, ideational, economic. It is with very great affection for a remarkable friend that I would like to dedicate this article to his memory.

** Robert Cowen is Professor Emeritus at the University College London, Institute of Education, where (in what was then called the Institute of Education, University of London) he has been a specialist in comparative education since 1976. He has also had the privilege of residing or working in various academic or consultancy capacities for considerable periods of time in Argentina, Australia, Brazil, China, Japan, South Korea, Sri Lanka, and the USA, as well as several countries in Europe. He is an Honorary Member of the Comparative Education Society in Europe and Chair of the Editorial Board of Comparative Education. His latest (2018) publications include 'Embodied Comparative Education', Comparative Education, 54(1), 10-25. Datos de contacto: E-mail: robert.cowen@ucl.ac.uk
} 


\begin{abstract}
There is a very large literature on Empires. There is a large literature on education and empires. However, there is only a small literature within comparative education on empires. Why? Given the numbers of people whose education was affected by Empires, given the stated intentions of those who created empires and imperial education systems, given the harmonies and tensions in most empires between politics and religion which played out in educational systems, and given some of the obvious differences between, say, the British, Dutch, French, Portuguese, Russian, Spanish and Soviet Empires and their discourses and practices in education, the silence is loud. This article will, first, reflect on the ways in which changes in 'comparative education' helped to construct that silence. Second, it will trace a more recent change in comparative education which opens up the possibility to re-assess Empires as a core theme of work, not just in the 'history of education' but in comparative education. That argument is pursued fully in the third section of the article. The conclusion notes yet another change in the political positioning of comparative education as a university subject and suggests that, despite new obstacles, empires ought to be a topic in our future and not just in our past.
\end{abstract}

Key Words: comparative education; empires; politics of knowledge

\title{
Resumen
}

Hay una gran cantidad de literatura sobre imperios. Hay una gran cantidad de literatura sobre educación e imperios. Sin embargo, solo hay un poco de literatura dentro de la educación comparada sobre imperios. ¿Por qué? Dado el número de personas cuya educación se vio afectada por los imperios, dadas las intenciones declaradas de quienes crearon imperios y sistemas educativos imperiales, dadas las armonías y tensiones en la mayoría de los imperios entre la política y la religión que se desarrollaban en los sistemas educativos, y dadas algunas de las diferencias obvias entre, por ejemplo, los imperios británico, holandés, francés, portugués, ruso, español y soviético y sus discursos y prácticas en la educación, el silencio es llamativo. Este artículo, primero, reflexionará sobre las formas en que los cambios en la «educación comparada» ayudaron a construir ese silencio. En segundo lugar, se trazarán los cambios más recientes en la educación comparada que abren la posibilidad de volver a evaluar los imperios como un tema central de trabajo, no solo en la «historia de la educación», sino en la «educación comparada». Ese argumento se persigue de lleno en la tercera sección del artículo. La conclusión señala otro cambio más en el posicionamiento político de la educación comparada como una materia universitaria y sugiere que, a pesar de los nuevos obstáculos, los imperios deberían ser para nosotros un tema de futuro y no solo del pasado.

Palabras clave: educación comparada; imperios; políticas del conocimiento 


\section{Introduction}

This article is about 'comparative education' and empires although, obviously, there are difficulties in analysing their relationship. What is loosely called 'comparative education' has developed a number of forms which are embedded in different political agendas and have different epistemic assumptions. The second problem is the reciprocal one: 'empires' change over time, and 'empires' can be very different in time and in place. Thus tracing, narrating, and analysing the relationships between comparative education and empires is like following a very complex dance which has an ambiguous, obscure, but culturally significant past. As in the tango, both partners shift shape, both partners sometimes seem to hear different music, and one partner seems to move rather more nimbly than the other ... yet the dance is meaningful only if they stay together. The theme of this article like the struggle in the tango becomes complicated and, as with the tango, the beginning is a loud silence.

How is it, why is it, that within comparative education there has been a silence about empires? And, when we do start to think about 'empires', what should we be looking at? What should we be looking for? Clearly, empires are not 'policy-problems-to-be solved' - our traditional concern for the last fifty years. Empires are of the past; they are for historians, are they not, and so what is it we ourselves should get to know about empires that would useful? Knowing about patterns of post-colonialism, a contemporary problem, might be useful; but Empires?

Clearly the answers to such questions depend heavily on a judgment about what comparative education is; and, by extension, what it does. Thus, before attention turns to 'empires', to clarify or to discipline the concept of comparative education is a sensible first step.

The structure of this article is simple although the themes, because of their interrelationships, gradually become complex. First, there is an analysis of comparative education itself, in two of its modalities. The argument is that academic comparative education (as it changed) created silences, which included a silence about empires. The second section of the article analyses another change in the identity of academic comparative education, a change which opens up coherent possibilities for discussion of the theme of empire. Accepting that possibility, the third and final part of the analysis asks: what is it in empires that is of great interest to comparative education - and why is that of great interest? The conclusion asks about the future and our responsibilities to it.

\section{Ways to think: comparative education}

There is not one comparative education but several. For example, there are different epistemic traditions, within educational studies, which affect how scholars in Canada, Denmark, Germany, Italy, Japan, Spain, the United Kingdom and the USA construct comparative education (Biesta, 2011; Palomba \& Cappa, 2018). Even the professional academic Societies have different names. Some people who make excellent contributions to comparative education, such as Tom Popkewitz in the USA, are based in departments of curriculum. Others who think comparatively such as Daniel Troehler in Vienna are, by self-definition, historians. The situation is confused and confusing.

How then to define 'comparative education'? There are three basic ways. 
One, the self-evident version, is irritating. There was, for a time, a fashion for judging which articles published in specialist journals were 'really comparative'. The definition of 'comparative' was juxtaposition. In other words, if a description of some aspect of education and society in Greece was placed next to a similar description of education and society in Greenland, then that article was 'comparative'. This child-like translation of the two words ('comparative' and 'education') did surprisingly little harm; it was a sort of party trick at family celebrations (e.g. in anniversary issues of journals such as Comparative Education Review or Comparative Education). It showed how much 'progress' had been made since last year's party trick. However, the party-trick was irritating: any bits of 'nationally-juxtaposed' research (e.g. measuring the happiness of teachers in Argentina and Andorra, or in Bogota and Brasilia) could be counted - literally - as comparative education. Nowadays, that simplistic concept of comparative education needs dismissal. That definition of comparative education, in its fixation with the surface 'form' of articles, distracts attention from questions of intellectual quality, theoretical power, problems of 'methodological nationalism' and the politics of knowledge in the social sciences.

More generally, the anxiety to assess 'the state of the art' of comparative education was a symbol of the academic nervousness of the field in the late 1970s. The damage done by the mid-Atlantic 'methods wars' in the mid-1960s had been considerable. Worse, the disaster was assumed to be about method, and it was not recognised for what it was: an ontological struggle, and a political re-positioning of the field as a policy science. Hence questions about 'the state of the art' were unintentionally quite sensible. By the mid1970 s there was indeed a strategic and historically significant question about 'the reading of the global' (Cowen, 2000a; 2009a) which was beginning to come into focus. Which aspects of the international world was the field of study seeing, which aspects had it not been seeing, and which aspects of the global did it now want to emphasise?

Thus the second basic way to define comparative education is to re-define it and call it 'international and comparative education' which, in the United States, included intervening in development and education in 'the Third Word.' This gradual political repositioning of comparative education is also visible in the names of some of our professional Societies. The American comparative education society, as the first comparative education professional society, refused the localism 'the American'; but used the word 'comparative'. It was CES; then it changed its title to The Comparative and International Education Society (CIES). The Japanese continue to have a Society called the Japan Comparative Education Society. Within Europe, the British (in retrospect rather ironically - the Brexit British?) left the Comparative Education Society in Europe (CESE) and became BAICE - the British Association for International and Comparative Education Society. The Italian Society, SICESE, retained its formal link with the Comparative Education Society in Europe (CESE) as a regional branch of the larger grouping. The Spanish Society having initially included the word 'pedagogical' in its title became SEEC (in English, the Spanish Comparative Education Society).

The crucial fulcrum for the decision of both the American and the British to use the word 'international' in the naming of their professional Societies was the theme of intervention in the third world and 'developing' it. That, indeed, finally became the title of a department in the Institute of Education within the University of London. Originally, from the late 1920s, one department - which predated the later, separate, department of comparative education by 20 years - had been named 'Education in the Colonies'. Clearly over time that title became both historically inaccurate and politically embarrassing. 
The new version, 'Education in Developing Countries' (EDC) combined a moral vision and an action programme - but was clearly also relevant to foreign policy and attracted resources from a range of agencies and networks, including the British Government's Department for International Development. In other words, the politics of knowledge of 'international and comparative education' are affected by its liaisons outside of the university with non-governmental aid agencies and governmental sources of funding in Washington and London; the political intent to reform the educational systems of other countries; and an academic agenda heavily influenced by the concept of 'gap' and theorisations of that gap: for example the gap between the former policy vision 'Education For All' and the failure to achieve it.

So where did that leave 'comparative education? Traditionally comparative education (in the UK) as a university-based academic study had used the perspective of history, and had written its descriptive narratives and done its academic thinking by reflecting on the political spaces which George Bereday called 'the northern crescent': initially Europe and North America (notably the USA); Russia and the USSR; and China and North Asia.

Three things came together to change academic comparative education.

First, the mid-Atlantic comparative education of the 1960s and 1970s reacted strangely to the Cold War. Steiner-Khamsi (2009) has traced the shift brilliantly for US comparative education, emphasising the creation of 'Sovietology' (and the subsequent lurch into 'Japanology'). More broadly, there was journalistic American anxiety about 'why Johnny cannot read but Ivan can'. Within academe and comparative education, there were books about the USSR and education, including Bereday, Brickman and Read (1960) and Harold Noah's doctoral thesis (1966) on the financing of Soviet schools. There was research, reported in the specialist journals, by the International Association for the Evaluation of Educational Achievement (IEA) about levels of achievement in the 'cold war' subjects of mathematics and the exact sciences. In the UK, there were small books by Janusz Tomiak $(1972 ; 1983)$ and by Nigel Grant $(1964 ; 1969)$ which provided accounts of what might loosely be called 'schools, society and progress' ${ }^{1}$ in the USSR. And there were big books by the Americans (DeWitt, 1955) describing such themes as Soviet policies for education in science and scientific manpower. But there was no major effort by academics in comparative education in the 1960 s to theorise revolution (in this case, the revolution of 1917), Marxist-Leninist ideology as a form of modernisation, Stalinism as a form of socialist mobilisation, and their consequent educational practices. Grant's book mainly described; it normalised Soviet society and its educational system. There was no comparative analysis of the USSR of the brilliance of R. H. Turner's "sponsored and contest mobilities" paper (1960) on the USA and the UK. A book that came close to moving beyond narrative - later - was by Ron Price (1977) on Communist China and the USSR; at least that began with Marx. However, the basic pattern was narration - an accumulation of area studies of the USSR. This non-theorising of the Cold War was one of the disasters that the 'methods wars' of the mid-1960s helped to create.

Thus the second major change was that the epistemic vision of the field of study narrowed: through an insistence (quite explicit in the writings of Noah and Eckstein) on positivist social science; and - through King and Holmes - an insistence on pragmatically useful forms of knowledge. The price of the hubris of the over-confident $1960 \mathrm{~s}$

1 The phrase is taken from a book series commissioned and edited by Edmund King. The books were written by area experts and had the common title 'Schools, Society and Progress'; and then 'China'; 'Eastern Europe'; 'France'; 'Israel' and so on. 
'scientists' of comparative education in the 1960s - such as Brian Holmes (1965) who actually claimed later that he had, himself. created a paradigm shift (1986) and Harold Noah and Max Eckstein (1969) and the fixation with policy of Holmes and Edmund J. King (1968) - was remarkably high. The price included a break with the historical gaze of comparative education, embodied by authors who had begun their academic writing in most cases in the 1930s: Nicholas Hans (1950; 1959; 1963), Isaac Kandel (1933; 1955), Friedrich Schneider (1961) and Robert Ulich (1964; 1968). Confirming and complaining about this break with history has been a motif in the writing of Andreas Kazamias (1963; 2001; 2009) for over fifty years.

The result, the third major change in academic comparative education, was a retreat from 'reading the global' (Cowen, 2018a). There was a retreat into domesticity. Comparative education began to fiddle with 'problem-solving', writing and advising on the fine-tuning of educational policies, and aspiring to be close to governmental power to do this. The embracement of a practical-reformist stance and a wish to work with politicians to 'improve' educational systems defined a very pragmatic orientation to academic work and meant that mid-Atlantic comparative education tended to pursue highly visible policy topics. This domestication of comparative education produced some very strange silences - strange, because a situation had developed in which:

"We silence history - and peoples. There are multiple silences, some of which are huge in human terms, notably silences about revolution; war; and Empires. Given we live in a period marked by the work of Theda Skocpol on revolutions, Tony Judt on the post-war period (after 1945) and excellent historical writing on Empire (such as Elkins on Kenya, Elliot and Thomas on the Spanish Empire, Hochschild on the Belgian Congo, Hoskin and Lieven on Russia, and Lawrence James on India) why has the comparative education literature been relatively silent?". (Cowen 2014a, p. 6)

In a simple sense, we know. The 'international' bit of international and comparative education was developing 'The Third World' - so it had no particular interest in looking backwards. And the tradition in academic comparative education had altered: it had lost its historical gaze. Instead it had turned inwards, taking its definition of relevance (and its definition of itself as useful to politicians) from domestic problems.

The irony is that comparative education was about to be rescued by that most domestic of persons, Mrs Thatcher, whose nationalism was obvious and aggressive, whose tolerance of the foreign was somewhat limited, and whose domestic political reforms were extremely courageous. Another shift, the third shift, in the nature of comparative education was about to occur.

\section{Ways to think: comparative education and Empires}

Mrs Thatcher and Mr Reagan remain excellent symbols of two important political changes which became more and more visible in the 1980s. One international form of economics and political ideology attracted the label 'globalisation' and the other, a change in domestic political formations, attracted the term 'neo-liberal state', oddly enough at a time when supra-national States were evolving. 
By and large, the challenge was recognised and there were major changes in the comparative education literature. One obvious effect was that books began to have the word 'globalisation' in their titles. There were a lot of such books - and there were some new words invented, like 'glocalisation'. Of course some of the books and some people (e.g. Bob Arnove, Carlos Torres) attempted to re-think seriously, for the purposes of comparative education, the major literature in historical sociology and political theory on globalisation; but many books merely had the word 'globalisation' in their titles, with the name of a sector of the educational system (e.g. secondary education, or teacher education) and ... offered juxtaposed descriptions of educational reform of that sector in many countries contemporaneously. It was 'old comparative education', re-wrapped.

The second effect within the literature of comparative education was major attention to the new political formations, the new kinds of States. In many countries, not least in northern Europe, the welfare State was being redefined and reconstructed as a neo-liberal state within a new vision of an economic world. In the same period, another new kind of state, the European Union, had helped to make the theme of the governance of education very salient (Lawn and Grek, 2012; Nóvoa \& Lawn, 2002; Ozga, Seddon \& Popkewitz, 2006). The literature was finally become interesting again.

There was a third effect: new statements about 'reading the global' began to be made.

Of course there had been earlier attempts to 're-read the global' (Arnove, 1980; Schriewer, 1990) but, from around 2000, the work picked up speed and intensity (Arnove, 2009; Beech, 2011; Carney, 2010; Cowen and Kazamias, 2009; Cowen \& Klerides, 2009; Larsen, 2010; Ninnes and Burnett, 2003; Ninnes and Mehta, 2004; Paulston 2009; Rappleye, 2012; Schriewer, 2012; Steiner-Khamsi, 2000; Steiner-Khamsi, 2004; Troehler, 2011; Welch, 2001). All of these authors, in different ways, were attempting a new 'reading of the global' which avoided the increasing imprecision of the concept of globalisation as it moved (from the analyses of writers such as Held and Roberston and Wallerstein) into 'educational studies'

The challenge was clear. Redefinitions of academic comparative education began to be generated. They all tended to be confident that 'an era' was coming to an end (Carney, 2010) but whether the way forward was via Bourdieu or Foucault or Luhmann or via a number of 'posts' (post-foundationalism, post-structuralism, post-modernity, and so on) were points of disagreement. However, there was a renewed emphasis on 'transfer': i.e. the movement of educational ideas, principles, policies and practices across national borders; albeit within an increasing level of agreement that such a concept was too unsubtle (Phillips, 2004; Phillips \& Ochs, 2003; Phillips \& Ochs, 2004). There was a new interest in 'shape-shifting' (Cowen, 2009b) to which Cowen and Klerides (2009) devoted a whole Special Issue of a journal.

At the same time, the growth of consultancies, and increased contract-funded research by all sorts of academics claiming they were 'doing comparative education' was becoming professionally embarrassing: it was clear that efforts needed to be made to distinguish various forms of 'applied' comparative education from academic forms of comparative education (Cowen, 2006). There was by no means a consensus on what the new academic form of comparative education should be. Steiner-Khamsi, for example, was thinking about a 'science of policy transfer'. Schriewer pursued 'horizons', 'externalisation', and 'meaning constellations in a world society'. Popkewitz analysed 'travelling libraries' and 'the indigenous foreigner' and (in an extremely interesting step forward) has began to discuss the concept of 'transnational history' (2013). Phillips (2014) created 
and discussed a new concept: 'comparatography'. The discussion continues with some energy, partly because of PISA and its visibility. It is often assumed (by politicians and the media) that PISA is 'good comparative education', despite a growing literature which suggests that the PISA project has a special identity as a form of politics and as a form of research (Grek, 2009; Meyer \& Benavot, 2013; Simola \& Risto, 2011); even if its empirical work is conducted in many countries and its results are certainly juxtaposed and 'inter-national'.

Thus it is becoming possible to suggest, within the last decade or so, that 'academic comparative education' has begun to reclaim its theoretical and intellectual identity; more precisely to claim a new one. That is, as a field of study based in universities, its task is to understand the mobility and the shape-shifting of 'education' as it moves transnationally amid the interplay of international and domestic politics.

Unfortunately, this cannot be a definition of a field of study. Why is 'the economic' not mentioned, where is the word 'cultural'? Who acts in this social world? At the point of 'interplay', is there a hierarchy of power, with the international being more important that the domestic? What mode, what kind of 'understanding' is being sought - what does 'understanding' mean? What does 'education' mean? As academics, we know that such a 'definition' would not survive two minutes in a university seminar.

However, as academics we can also instantly see the point of the aphorism (for educational ideas, principles, institutions, and so on): 'as it moves, it morphs'. The ideas of John Dewey travelled to a remarkable number of countries which included Brazil, China, England, Japan, Mexico, Russia, South Africa and Turkey. Simply telling the story of such events - the narration - is hard enough. Interpreting what happened to Dewey and his ideas - or to Protestantism moving internationally - requires some concept of shapeshifting (Popkewitz, 2008; Troehler, 2011).

And, of course, the principles and the questions apply to empires. If we are 'to understand the mobility and the shape-shifting of 'education' as it moves transnationally amid the interplay of international and domestic politics', then the classical political Empires are an obvious theme. The aphorism 'as it moves, it morphs' has room to play...

The literature on empires is remarkably large. On the history of the British Empire alone, for example, Oxford University Press has published five volumes (Louis, 1999) and the work keeps coming. Niall Ferguson (2003), being of a certain age, was able to link his major book on the British Empire to named members of his family and relatives whose lives had taken them to different parts of the Empire, for different reasons. Brendon (2007), less enamoured of the Empire, concentrated on its decline and fall. As might be expected, very interesting work has also been done by historians of education in the United Kingdom on the theme of Empire (Mangan, 1986; Mangan, 1988; Mangan 1993). The theme of much of that work - also as might be expected - has been elites and elite formation. Local elites (e.g. in Canada or India) were often educated in schools which imitated Scottish or English traditions, and for many families in the United Kingdom, the Empire was both a career and a life. Some schools in Britain - typically 'private' schools, with their 'preparatory' sector (LeinsterMackay, 1988) and then the so-called 'the public schools' - offered an approximate socialisation for imperial leadership; though training for colonial leadership in India was particularly selective (Whitehead, 2003). Rupert Wilkinson (1964) has offered a brilliant comparison of training for leadership in the public schools, in counterpoint with the Chinese literati. Overall, again as might be expected, the bibliography on education in imperial India - that, is just on India and just on education - is impressively large (Whitehead, 2005). 
It is clear, from journals such as Paedogogica Historica and a basic bibliographic search, that similar literatures are available in a range of other languages for a range of other Empires (as the articles in Portuguese and Spanish in this monograph section also illustrate). Thus, there is a great deal of existing material against which to put basic questions, such as what kinds of 'education' were distributed within Empires, to whom, and why and how were these forms of education distributed?

Answers to those questions very rapidly offer an orientation to the ways in which Empires confirmed or contradicted local stratification systems, such as caste; aimed at inclusion of all in an educational process that stressed a common identity (such as Christianity; or accepted (or even sought) the subordination or marginalisation of a minority group in a newly occupied territory such as the USA or Australia. Clearly a crucial discussion in Empires is whether those conquered should be offered education at all. The decision in Spain that the indigenous inhabitants of the New World had souls was one direction. Within the Nazi Empire, the decision to distribute education in accordance with the principles of Nazi race theory led in a different direction.

Answers to those questions very rapidly confirmed the range of mixtures of State and religious power which framed imperial projects. At one extreme, the Catholic Church was a partner with the Spanish and Portuguese States in Latin America. At the other, the Soviet State was prepared, at best, to make some educational concessions to a powerful organised religion (but rather more for example in Poland and in the Muslim Republics of the USSR, than in Mother Russia itself).

And of course the Church-State balance was not a policy that was always universalised for a whole empire. Within the British Empire for example, missionaries were not warmly welcomed in India at the time of the East India Company (partly because of the political dangers of upsetting large religious groups within the Indian population); whereas in the West Indies and in much of those parts of Africa that the British colonised, the missionary was symbolised by David Livingstone whose visibility was considerable, who was useful as a anti-slavery symbol, and who was not always effective in practice. The point perhaps is to note that there was a mix of State and religious power within Empires in Africa, including in the Belgian, French, German and Portuguese empires. This mix of secular power, commercial interest, religious belief, and ideologies about 'civilisation' was extraordinarily complex (as in South Africa); but by the time of 'The Scramble for Africa' (say 1880 onwards until World War One) an extra layer of answers could be sketched to the questions: what kinds of 'education' were distributed within Empires, to whom, and why were these forms of education distributed?

There remain other crucial questions, such as how the Muslims and Hindus of the Indian sub-continent - male and female - used such education as the British offered, or the Malays, Chinese and Indians within what was at that time Malaya took advantage of the educational patterns of the period, or the Turks and Greeks in Cyprus and so on - and for other Empires also. Who among the colonised completed their education in French, or indeed in French and in Paris?

However, amid the sketches of the kinds of work which historians have already done and amid sketches of the considerable narrative complexities needed to answer some basic questions about the distribution of education within empires, two other questions have been marginalised. One of those questions was about shape-shifting and Cowen's aphorism: as it moves, it morphs? And the second question asked much earlier was: 'what is it in empires that is of great interest to comparative education - and why is that 
of great interest?' Answers to those questions create ways to think about Empires in comparative education. However, the point is not to indicate two or three themes which define a job list. The last thing at the present moment which comparative education needs is a set of sensible job lists. Rather, along with the other articles in this monograph section of the journal, the core purpose remains: to open up perspectives on new ways to think about empires.

\section{Ways to think: Empires}

Empires come and go. However, something extra can be said which turns that banality into an interesting idea: empires come and go and as they come and go they create 'transitologies' (Cowen, 1999; 200ob). A transitology is - in a period of about ten years - the rapid destruction or collapse and reconstruction of state apparatuses; economic and social stratification systems; political visions of the future; and the deliberate use of the educational system to move such visions forward.

One illustration would be the England of Mrs Thatcher. Part of her electoral appeal was the intention to create 'a small State'; to discipline the trade unions and to favour entrepreneurship and small-scale capitalism, to reassert Britain's international position, and prepare it for an economically globalised world. The agenda she promised in her first election manifesto was followed. The nationalised industries - such as coal, steel, the railways, energy industries, aviation - were sold into private ownership. There was the famous struggle between the Government and the coal miners' trade union, and the beginning of a shift in wealth - which continues up to the present: in England, the rich have grown richer and the poor poorer. The rhetoric about economic globalisation has - forty years later - only just begun to diminish. (In part, Brexit can be understood as a rejection of it, by much of the British electorate.) In particular, in the 1980 s there was a flurry of educational reform - designed very much to construct a new future. In England (Scotland controls its own educational system) there were changes in the system of governance of education: an interesting shift in which many aspects of educational control were centralised in London and other aspects were located at school level - intentionally weakening control by local education authorities, not all of which shared the visions of the Conservative Party about 'effective and efficient' schools. There were reforms of school curricula, the introduction of standardised tests for all children at particular ages, the publication of school league tables, reforms of teacher education (which became more and more school-based), and the beginnings of the disciplining of universities by measuring their output as if they are economic units, rather than a part of civic society and - for that reason - vital to the cultural and political public life of the nations within the UK.

Transitologies, then, are political events which are not limited to Empires. Nor do they have an axiomatic connection to revolutions, oddly enough. While revolutions are intended and actually may achieve many of the same things (altering state apparatuses, redefining social and economic stratification systems, and offering visions of a new future), revolutions can take years. Exactly how long 'the Chinese Revolution' took can be debated. However, one definition would be to say that it was a number of revolutions which began even before 1911 and that it took until 1949 when the Chinese State was formally re-stabilised. However, China did have a transitology: the remarkable Cultural Revolution of the mid-1960s which redefined State apparatuses (including inventing the Red Guards); which dramatized ('learn from the workers, soldiers, and peasants) 
extreme policies for re-shaping social and economic stratification systems; and which with the Little Red Book painted a very Maoist (and not merely a Marxist-Leninst) view of the future. In contrast, the Cuban Revolution was that - and also a transitology. Within a period of about ten years, Fidel Castro tackled each of the motifs of a transitology reconstructing State apparatuses, redefining social and economic stratification systems, confirming the vision of the future in interminable speeches, and he used the educational system to support all of these initiatives.

What is very noticeable in the Cuban case is that the transitology redefined Cuba's international political relations. In the example of China and the Cultural Revolution there was a refinement of international political and economic relations with the USSR - the links became less enthusiastic, but they survived. Similarly with Mrs Thatcher: there was no abrupt redefinition of international political relations, but the links with continental Europe became more acrimonious, and those with the USA more harmonious. Changes in international political and economic relations are not an axiomatic part of a transitology.

In contrast, Empires, as they 'come and go', are themselves huge changes in international and political and economic relations - and they create transitologies. Among contemporary examples, the 'exit' transitologies of central and Eastern Europe are striking (Silova, 2010). The eastern European post-imperial patterns meet all of the criteria of a transitology - as well as being marked by major changes in international political relations. The transitology for 'East Germany', after the symbolic and actual collapse of the Wall, is perhaps the most extreme example given its absorption into an existing State ('West Germany') and the reversal of its international political relations.

Thus Empires tend to create what Alistair Horne (1978) called 'savage wars of peace' - and transitologies on exit (Algeria, Cambodia, India, Indonesia, Laos, Pakistan, 'Palestine', Tanzania, Vietnam, Uganda) and as Empires advance they create transitologies. This - apart from classical political conceptions of an inter-national balance of power and of a geo-political 'buffer zone' of satellites - was the point of the expansion of the USSR into central and eastern Europe in the first place. Visions of the future were being exported; and, with that, visions of a 'good educational system' and the proper purposes of education. This for the Spanish, early, was part of empire building in southern America and, rather more slowly and gradually, a definition of the proper purpose of 'good education' for indigenous peoples emerged in northern America. The social and cultural destruction inflicted on indigenous peoples in the name of 'good education' has created a large literature offering to us disturbing historical and comparative counterpoint.

We - as 'indigenous peoples', local peoples in our national tribes - are now faced with the enthusiasms of PISA and the World Bank for the educational future of our grandchildren.

However, as disturbing as such historical memories and visions of the future might be, they should not be permitted to distract attention from the core academic question: in addition to noting some of the tragedies of empire and in addition to the excitement of noting the remarkable number of exploding stars (i.e. transitologies) that occur as the waves of empire advance and recede - what is the point of transitologies and Empires for comparative education?

The point is a theoretical point very relevant to comparative education. I did not invent the concept of transitology to count exploding stars, or political black holes, or 
to prove that social universes begin with a Big Bang. The theoretical point is that transitologies, in a very compressed form, might contain a key to the codings of educational systems: 'coding' here means the ways in which social power (economic, political cultural) is compressed into specific educational shapes, such as curriculum, or concepts of universities, or educated identities. In a transitology, we see intense moments of social creativity: we are offered new visions of societies. And we are offered even more: we are seeing new definitions of 'the State'; we are seeing new conceptions of 'an educational system', and new definitions of 'educated identity'.

We may be seeing new 'codings'; but we cannot read them yet.

Combine this theme, then, with 'Empires' - which are themselves new forms of State with remarkable variation between the Austro-Hungarian, the so-called Brazilian Empire, and the British, French, German, Ming, Ottoman, Roman, Russian and Soviet forms of empire.

And combine these two themes with the display - in empires - of most of the 'unit ideas' $^{\prime 2}$ of comparative education. The 'unit ideas' of comparative education are: transfer; the educational system; the State; educated identity; space; time; social context; and praxis (Cowen 2002; 2009a). What I am calling unit ideas are 'our' unit ideas - specific mixtures of these ideas run throughout the history of comparative education as a field of study and hekp to hold it together as a field of study.

Quite remarkably - the theme of 'Empires' cuts to the heart of unit ideas and to the theoretical concerns of comparative education.

The State? Empires themselves are new forms of State as they expand clash with earlier forms of State and earlier forms of 'education.' Transfer? The insertion of French educational institutions into Algeria is embedded (obviously with different educational results) in a very different politics compared with the insertion of English educational patterns into Ghana. In turn, Ghana was a very different example of the 'transfer' of education compared with the even more complex situation in South Africa. The educational system? Which 'parts of' an educational system would be 'exported' was also a decision that needed to be taken - for example whether, in the imperial period, 'a university' or a college for the applied social sciences should be created in twentieth century Malaya was discussed within an Advisory Commission in London. There were similar debates over the provision of academic secondary school education or vocational-technical education at school level (e.g. in Ghana). There was in Victorian England a famous debate about whether English or languages and literatures indigenous to India should be encouraged. Context? The insertion of 'English' educational forms into India involved a careful assessment of what comparative educationists have been fixated about for at least 120 years: the very slippery concept of 'social context' which as a concept has posed an almost intractable problem for comparative education for over one hundred years. ${ }^{3}$. Praxis? All these decisions, interventions, and exportations were remarkable acts of imperial praxis.

As usual, the unit ideas most difficult to illustrate - and among the most interesting - are space and time (Cowen, 2018b). These ideas still need to be worked out (for comparative education) within the theme of 'empire'.

2 The term 'unit ideas' comes from Robert Nisbet and his impressive interpretation of sociology as a field of study defined, over the generations, by a small number of ideas. He calls those the 'unit ideas' of sociology.

3 The phrase has just about reached the point where it has become analytically useless, though fresh insights into the concept (Sobe \& Kowalczyk, 2018) will at least prevent the word 'context' being used as a professional mantra. 
However, the unit idea of 'educated identity' is also fascinating and relatively easy to illustrate quickly. Indeed, there are examples in this monograph section of the journal. Iveta Silova and Garine Palandjian show how the concept of educated identity includes ceremonies and rituals and uniforms in the socialisation offered within State-dominated youth groups in the Soviet empire. The theme of 'socialised identity' in empires is also illustrated superbly by Ann Stoler (2001) who has shown how the concept of 'educated identity' in empires very rapidly extends beyond formal education and includes sensibility to the rules of empires in the physical gestures, sexual relationships and 'tender ties' and intimate relationships (including in the play and leisure of children) between the colonisers and the colonised. Funie Hsu (2013) has also argued, brilliantly, to show how the maternalising and caring identity of those American females teaching English, following Public Law 74 in 1901 in the Philippines, helped to "erase" the fact that colonisation of identity was occurring. Rupert Wilkinson's work (1964) on the 'educated identity' of those headed towards imperial rule has already been indicated but another of his classic essays - on the education of Janissaries within the Ottoman Empire - has not; nor has the pattern of reforms of Kemal Atatürk which included injunctions against the use of the fez in male attire been mentioned as part of the transitology at the end of an Empire.

The examples of reforms aimed at the definition of 'educated identity' in Empires could be extended. Major work on gender and race and educated identity has not been traced. The range of empires which has been mentioned, never mind properly analysed, has been limited. No effort has been made to utilise a theme recently popular among British historians of education - the effects of Empire on education in Britain (under the general rubric 'the empire strikes back') or rather more charmingly, the effects of Empire on themselves as historians (Burton \& Kennedy, 2018).

However, perhaps enough has been said to hint at a flurry of 'shape-shiftings' necessarily associated with education and empire and in particular to sketch an answer to the question, what is it in empires that is of great interest to comparative education - and why is that of great interest? The short answer is that both transitologies and changes in 'unit ideas' are very visible amid the political, cultural, economic and ideational struggles which go on within Empires, as they come and go... and that both transitologies and reallife changes in unit ideas are important parts of what our academic work in comparative education seeks to understand.

So what happens next? There is, surely, a happy ending?

Perhaps not. As any old-style imperialist will tell you, happy endings - even if one can survive the beginnings of Empire - do not always come to those who think they deserve them.

\section{A Happy Ending?}

First comes one Englishman, as a traveller or for shikar; then come two and make a map; then comes an army and takes the country. Therefore it is better to kill the first Englishman.

Afghan proverb

There are some stabilities, in addition to the irritation of Afghans after four wars with the 'English'; though that is an insult, en passant, to the Northern Irish, the Scots and the Welsh, some of whom were excellent imperialists (Allen, 2001). There are continuations, 
epilogues, post-scripts. When the imperial flags are lowered, the plangent tones of the trumpets die, and the armies march away, the 'Empire' does not end. It begins to become... for example, a brilliant outburst of writing talent: Achebe, Fanon, Gordimer, Rushdie, Said. The empire also becomes memories carried harshly in stone, in cathedrals and graves, memories captured in archives in Bombay and Buenos Aires and Rio de Janeiro, in bits of broken bombers in Vietnam and monuments to the martyrs of Independence in Algeria and in terrifying museums in Shanghai about the Japanese occupation. The memories and meanings of 'empire' are also rewritten in a range of academic discourses with different intellectual histories and, no doubt, different intellectual futures: dependencia; Orientalism; and post-colonialism (Takayama, Sriprakash \& Connell, 2016). There are other ironic stabilities close to home too: comparative education, an academic subject traditionally linked to the training of teachers and to MA and PhD programmes and academic qualifications, is changing yet again. In one identity - as funded research, as consultancies, and in advisory roles in fragile States and post-conflict struggles for peace - it is rapidly taking up a role akin to medicine: the role of an applied science; albeit a rather unreliable one at the present moment, even though, as an academic subject, comparative education is now under severe pressure to offer research that is 'robust and relevant'.

The current politics of knowledge in the UK stress the importance of a certain kind of research training (Cowen, 2016) and in the UK and and increasingly in Europe, there is an assertion that the research of academics should have rather rapid social and economic impact (Cowen, 2012; Gunn \& Mintrom, 2016). Those definitions of 'quality' do not encourage theory work (Cowen, 2012). This does not mean that theory work is not being done; but not a lot of it is done in England. New ideas created in Europe, and the United States, and Australia and Japan are visible: Carney, Rappleye and Silova (2012); Paulston (2009); Schriewer (2012); Troehler (2011) and McLeod, Sobe and Seddon (2018). In England, more typical from senior management in universities is the plea for the kind of relevance which might appeal to politicians, for example, Patricia Broadfoot's remarkably explicit advocacy of 'learnology' (2009). The pressure is towards the useful and measurable, a return to time-past. Once again, the vision of comparative education is being narrowed. Having epistemically uprooted itself from concerns with the domestic and its obsessions with 'critical points of decision' and 'problem-solving' in the 1960s and 1970s, comparative education is now, under national and university managerial pressures, being disciplined (Cowen, 2007; 2013). In earthier language it is being expected, like a chicken, to come home to roost.

That is extremely unfortunate. The World Bank or OECD or PISA are not merely sources of 'solutions' to educational problems but are also part of the construction of a new problem: a new vision of new inter-national ways of re-shaping and governing educational systems, and transmitting ideologies of positivistic performance and economic efficiency, in which education is reduced to skill acquisition (Cowen, 2014b). These are the new forms of empire; subtler empires, neo-empires, empires of the mind.

Indeed, it is here that I would like to acknowledge the significance of the comments of one of the external reviewers of this article. ${ }^{4}$

$4 \quad$ The reviewer pointed out that the article could have given greater stress to the theme of 'empires' and the future. I agree. My essay in its present form, like most of the other essays in this monograph section of the journal, emphasises the historical implications of empires for comparative education per se. In particular, my essay tried to interpret when and why comparative education 'shape-changed' and when and why it was silent about empires. And why it should not be silent about empires. The external reviewer 
Given those proposed themes which are excellent, what is ironic, here, is that the theme of the domination of 'the economic' is precisely the theme which is re-domesticating comparative education - along with the relative quiescence of new cadres of academic leadership in universities (in a range of neoliberal states) about political propositions that stress that the crucial role of the university is to drive 'the knowledge economy' forward; that agree it is the proper role of the university to behave as-if it is a profit making economic institution; and that accept that models of research training should be defined and academic quality regularly and routinely measured by administrative agencies external to the university which emphasise the 'social impact' of university research. In this messianic vision of economic success and efficiency - while there is indeed recognition of the new importance of 'identity politics'- there is a disturbing silence over the emergent patterns of 'knowledge societies' and silence over the classic and historical question of the relationships of economies to new forms of social stratification, educational discrimination, and social injustice. In other words, as with the Industrial Revolution, the huge historic questions of the relationship of economies to new forms of society.

It is our proper concern as educationists to investigate these new forms of imperium that shape and re-shape 'educational systems', exactly at the intersections of international and domestic power. It is our responsibility to look outwards and upwards and critically; not merely to support the Minister in his wish to import Chinese teachers from Shanghai. This is the worst possible answer to the famous question of Sir Michael Sadler: 'what can be learned from the study of foreign systems of education'. Ministers come and go. We do not, and we have read things and understood things that the Minister has not. We are not chickens that come home to roost.

Our proper position is to be separated from power and critical of it. Our voice, our responsible voice, is that of Cassandra. Our intellectual puzzle remains: 'as it moves, it morphs'. Our moral responsibility, our professional moral responsibility, is unvarying: as best we can, to the maximum of our academic, analytical and scholarly talents, we bear witness to what is done, in many places and in many times under the impact of multiple forms of power, to human beings in the name of education. Thus, among other things, we study Empires of the past, empires in the present, and, yes, the emergent empires of the future.

\section{References}

Allen, C. (2001). Soldier Sahibs: the men who made the North-West Frontier. London: Abacus.

Anderson-Levitt, K. (Ed.) (2003). Local meanings, global schooling: anthropology and world culture theory. New York: Palgrave Macmillan.

Arnove, R. F. (1980). Comparative education and world systems analysis. Comparative Education Review, 24(1), 48-62.

Arnove, R. F. (2009). World-systems analysis and comparative education in the age of globalisation. In R. Cowen \& A. M. Kazamias (Eds.), International Handbook of Comparative Education (pp. 99-117). Dordrecht: Springer.

sketched an extra set of excellent ways for comparative education to move forward, in terms of modes of domination on at least four dimensions: the economic; space (including electronic space); the image (rather than 'word'); and language (and its automatic construction of 'others' who become 'minorities'). 
Beech, J. (2011). Global panaceas, local realities: international agencies and the future of education. Frankfurt-am-Main: Peter Lang.

Bereday, G. Z., Brickman, W.W, \& Read, G. H. (Eds.) (1960). The Changing Soviet School: The Comparative Education Society field study in the U.S.S.R. Boston: Houghton Mifflin Company.

Biesta, G. (2011). Disciplines and theory in the academic study of education: a comparative analysis of the Anglo-American and Continental construction of the field. Pedagogy, Culture \& Society, 19(2), 175-192.

Brendon, P. (2007). The decline and fall of the British Empire. London: Cape.

Broadfoot, P. (2009). Time for a scientific revolution? From comparative education to Comparative Learnology. In R. Cowen \& A.M. Kazamias (Eds.), International Handbook of Comparative Education (pp. 1249-1266). Dordrecht: Springer.

Burton, A. \& Kennedy D. (Eds.) (2018). How Empire shaped us. London: Bloomsbury Academic.

Carney, S. (2010). Reading the global: comparative education at the end of an era. In M. Larsen (Ed.), New Thinking in Comparative Education: Honouring the work of Robert Cowen (pp. 125-142). Rotterdam: Sense Publishers.

Carney, S., Rappleye, J. \& Silova I. (2012). Between Faith and Science: world culture theory and comparative education. Comparative Education Review, 36(3), 366-93.

Cowen, R. (1999). Late modernity and the rules of chaos: an initial note on transitologies and rims. In R. Alexander, P. Broadfoot and D. Phillips (Eds.), Learning from comparing: new directions in comparative educational research, vol.1, contexts, classrooms and outcomes (pp. 73-89). Oxford: Symposium Books.

Cowen, R. (2000a). Comparing futures or comparing pasts? Comparative Education, 36(3), 333-342.

Cowen, R. (200ob). Fine-tuning educational earthquakes? In D. Coulby, R. Cowen \& C. Jones (Eds.), World Yearbook of Education 200o: Education in times of transition (pp. 1-7). London: Kogan Page.

Cowen, R. (2002) Sketches of a Future'. In M. Caruso \& H. E. Tenforth, (Eds.), Internationalisierung: Semantik und Bildungsstem in vergleichender Perspektive [Internationalisation: Comparative education systems and Semantics] (pp. 271283). Peter Lang: Frankfurt-am-Main.

Cowen, R. (2006). Acting comparatively upon the educational world: puzzles and possibilities. Oxford Review of Education, 32(5), 561-573.

Cowen, R. (2007). Comparing and transferring: visions, politics and universities. In D. Bridges, P. Juceviciene, R. Jucevicius, T. McLaughlin \& J. Stankeviciute (Eds.), Higher education and national development: universities and societies in transition (pp. 13-29). London: Routledge. 
Cowen, R. (2009a). Then and Now: Unit Ideas and Comparative Education. In R. Cowen \& A.M. Kazamias (Eds.), International Handbook of Comparative Education (pp.1277-1294). Dordrecht: Springer.

Cowen, R. (2009b.) The transfer, translation and transformation of educational processes: and their shape-shifting? Comparative Education,45(3), 315-327.

Cowen, R. (2012). Robustly Researching the Relevant: a note on creation myths in comparative education. In L. Wikander, C. Gustaffson \& U. Riis (Eds.), Enlightenment, Creativity and Education: polities, politics, performances (pp. 3-26). Rotterdam: Sense Publishers \& CESE.

Cowen, R. (2013). Changing Principles and Goals of Universities: questioning trajectories, Sisyphus: journal of education. Institute of Education, University of Lisbon, 1(2), 38-53.

Cowen, R. (2014a). Comparative education: stones, silences, and siren songs. Comparative Education, 5o(1), 3-14.

Cowen, R. (2014b). Ways of knowing, outcomes and 'comparative education': be careful what you pray for. Comparative Education, 5O(3), 282-301.

Cowen, R. (2016). Doctoring the Doctorate in England. In D. Palomba \& C. Cappa (Eds.), Knowledge Society and Doctoral Studies: Research, Education and Training in a New Landscape (pp. 81-116). Rome: Aracne.

Cowen, R. (2018a). Embodied Comparative Education. Comparative Education, 54(1), 10-25.

Cowen R. (2018b). The warp and weft of comparative education: time and space. In J. McLeod, N. Sobe \& T. Seddon (Eds.), Uneven Space-Times in Education: historical sociologies of methods and practices, World Yearbook of Education 2018 (pp. 2640). London and New York: Routledge, Taylor and Francis.

Cowen, R., \& Kazamias, A.M. (Eds.). (2009). International Handbook of Comparative Education. Dordrecht: Springer.

Cowen, R., \& Klerides, L. (Eds.) (2009). Mobilities and educational metamorphoses: patterns, puzzles, and possibilities [Special issue]. Comparative Education, 45(3).

DeWitt, N. (1955). Soviet professional manpower: its education, training and supply. Washington, DC: US Government Printing Office.

Ferguson, N. (2003). Empire: How Britain made the modern world. London: Allen Lane.

Grant, N. (1964). Soviet Education. Harmondsworth: Penguin.

Grant, N. (1969). Schools, society and progress in Eastern Europe. Oxford: Pergamon Press.

Grek, S. (2009). Governing by numbers: The PISA effect in Europe. Journal of Education Policy, 24(1), 23-37.

Gunn, A., \& Mintrom, M. (2016). Higher education policy change in Europe: academic research funding and the impact agenda. European Education, 48(4), 241-257. 
Hans, N. (1950). Comparative Education: A study of educational factors and traditions (2nd edition). London: Routledge \& K. Paul.

Hans, N. (1959). The historical approach to comparative education. International Review of Education, V(3), 299-307.

Hans, N. (1963). The Russian tradition in education. London: Routledge and Kegan Paul.

Holmes, B. (1965). Problems in education: a comparative approach. London: Routledge \& Kegan Paul.

Holmes, B. (1986). Paradigm shifts in comparative education. In P. G. Altbach, \& G. P. Kelly (Eds.), New approaches to comparative education (pp. 179-199). Chicago: The University of Chicago Press.

Horne, A. (1978). A Savage War of Peace: Algeria 1954-1962. New York: Viking Press.

Hsu, F. (2013), Colonial Articulations: English Instruction and the 'benevolence' of U.S. overseas expansion in the Philippines, 1898-1916 (unpublished doctoral dissertation). University of California, Berkeley, California.

Kandel, I. L. (1933). Comparative education. Boston: Houghton Mifflin.

Kandel, I. L. (1955). The new era in education: a comparative study. Boston: Houghton Mifflin.

Kazamias, A.M. (1963). History, science and comparative education: a study in methodology. International Review of Education, 8(3-4), 383-398.

Kazamias, A. M. (2001). Re-inventing the historical in comparative education: reflections on a protean episteme by a contemporary player. Comparative Education, 37(4), 439-449.

Kazamias, A. M. (2009). Reclaiming a lost legacy: the historical humanist vision in comparative education. In R. Cowen, \& A.M. Kazamias (Eds.), International Handbook of Comparative Education (pp.1267-1276). Dordrecht: Springer.

King, E. J. (1968). Comparative studies and educational decision. London: Methuen.

Larsen, M. (Ed.) (2010). New Thinking in Comparative Education: Honouring the work of Robert Cowen. Rotterdam: Sense Publishers.

Leinster-Mackay, D. (1988). The nineteenth-century English preparatory school: cradle and crèche of Empire? In J. Mangan, (Ed.), 'Benefits Bestowed? Education and British Imperialism (pp. 49-69). Manchester. Manchester University Press.

Louis, W. (Ed.) (1999). The Oxford History of the British Empire (5 vols). Oxford: Oxford University Press.

Mangan, J. A. (1986). The Games Ethic and Imperialism: aspects of the diffusion of an ideal. London: Viking.

Mangan J. A. (Ed.) (1988). 'Benefits Bestowed'? Education and British Imperialism. Manchester: Manchester University Press. 
Mangan J. A. (Ed.) (1993). The Imperial Curriculum: racial images and education in the British colonial experience. London: Routledge.

McLeod, J., Sobe, N. \& Seddon, T. (Eds.) (2018). World Yearbook of Education 2018, Uneven Space-Times of Education: historical sociologies of concepts, methods and practice. London: Routledge.

Meyer, H. D., \& Benavot, A. (Eds.) (2013). PISA, Power and Policy: The emergence of global educational governance. Oxford: Symposium Books.

Ninnes, P., \& Burnett, G. (2003). Comparative Education Research: poststructuralist possibilities. Comparative Education, 39(3), 279-297.

Ninnes, P., \& Mehta, S. (Eds.) (2004). Re-imagining Comparative Education: Postfoundational ideas and applications for critical times. New York: Routledge.

Nisbet, R. A. (1967). The Sociological Tradition. London: Heinemann.

Noah, H. (1966). Financing Soviet schools. New York: Teachers College Press.

Noah, H.J., \& Eckstein, M.A. (1969). Toward a science of comparative education. New York: Macmillan.

Nóvoa, A., \& Lawn, M. (Eds.) (2002). Fabricating Europe: the formation of an education space. Dordrecht: Kluwer Academic Publishers.

Ozga, J., Seddon, T., \& Popkewitz, T. S. (Eds.) (2006). World Yearbook of Education 2006, Education Research and Policy: steering the knowledge-based economy. London: Routledge.

Palomba, D., \& Cappa, C. (Eds.) (2018). Comparative studies in education in Southern Europe [Special Issue]. Comparative Education, 54(3).

Paulston, R. (2009). Mapping comparative education after post-modernity. In R. Cowen \& A.M. Kazamias (Eds.), International Handbook of Comparative Education (pp. 965-990). Dordrecht: Springer.

Phillips, D. 2004. Toward a Theory of Policy Attraction in Education. In G. SteinerKhamsi (Ed.), Lessons from Elsewhere: The politics of educational borrowing and lending (pp. 54-67). New York: Teachers College Press.

Phillips, D. (2014). 'Comparatography', history and policy quotation: some reflections. Comparative Education, 5o(1) 73-83.

Phillips, D., \& Ochs, K. (2003). Processes of Policy Borrowing in Education: Some analytical and explanatory devices. Comparative Education, 39(4), 451-461.

Phillips, D., \& Ochs, K. (Eds.) (2004). Educational Policy Borrowing: historical perspectives. Oxford: Symposium Books.

Popkewitz, T. S. (2008). Inventing the Modern Self and John Dewey: modernities and the travelling of pragmatism in education. New York: Palgrave Macmillan.

Popkewitz, T.S.(Ed.) (2013). Rethinking the history ofeducation: transnational perspectives on its questions, methods and knowledge of schools. New York: Palgrave. 
Price, R. F. (1977). Marx and Education in Russia and China. London: Croom Helm.

Rappleye, J. (2012). Educational Policy Transfer in an Era of Globalization: Theory History - Comparison. Oxford and New York: Peter Lang.

Schneider, F. (1961). The Immanent Evolution of Education: A neglected aspect of comparative education. Comparative Education Review, 4(1), 136-139.

Schriewer, J. (1990). The Method of Comparison and the Need for Externalization: Methodological criteria and sociological concepts. In J. Schriewer in cooperation with B. Holmes (Eds.), Theories and Methods in Comparative Education (pp. 2583. Frankfurt: Peter Lang.

Schriewer, J. (Ed.) (2012). Reconceptualising the Global/Local nexus: Meaning constellations in the world society [Special Issue]. Comparative Education, 48(4).

Simola, H. and Risto, R. (2011). Education Policy and Contingency: belief, status and trust behind the Finnish PISA Miracle. In M. A. Pereyra, H-G. Kotthoff \& R. Cowen (Eds.), PISA Under Examination: Changing Knowledge, Changing Tests, and Changing Schools, (pp. 225-244). Netherlands: Sense Publishers.

Stoler, A. L. (2001). Tense and tender ties: The politics of comparison in North American history and (post) colonial studies. Journal of American History, 88(3), 829-865.

Silova, I. (Ed.) (2010). Post-socialism is not dead: (re)reading the global in comparative education. UK: Emerald Group Publishing Limited.

Sobe, N. \& Kowalczyk, J. (2018). Context, entanglement and assemblage as matters of concern in comparative education research. In J. McLeod, N. W. Sobe, T. Seddon (Eds.), Uneven Space-Times in Education: historical sociologies of methods and practices, World Yearbook of Education 2018 (pp. 197-204). London and New York: Routledge, Taylor and Francis.

Steiner-Khamsi, G. 2000. Transferring Education, Displacing Reforms. In: J. Schriewer (Ed.), Discourse formation in comparative education (pp. 155-187). Frankfurt am Main: Peter Lang.

Steiner-Khamsi, G. (Ed.) (2004). Lessons from Elsewhere: The politics of educational borrowing and lending. New York: Teachers College Press

Steiner-Khamsi, G. (2009). Comparison: Quo vadis? In R. Cowen \& A. M. Kazamias (Eds.), International handbook of comparative education (pp. 1143-1158). Dordrecht: Springer.

Takayama, K., Sriprakash, A, \& Connell, R. (2016). Towards a postcolonial comparative and international education. Comparative Education Review, 61(S1), 1-24.

Tomiak, J.J. (1972). World Education Series: The Soviet Union. Hamden: Archon Books.

Tomiak, J. J. (Ed.) (1983). Soviet education in the 1980s. London: Palgrave Macmillan.

Troehler, D. (2011). Languages of education: Protestant legacies in educationalization of the world, national identities, and global aspirations. New York: Routledge. 
Turner, R. H. (1960). Sponsored and Contest Mobility and the School System. American Sociological Review, 25, 855-67.

Ulich, R. (1968). History of Educational Thought (revised edition). Chicago: American Book Company.

Ulich, R. (Ed.) (1964). Education and the Idea of Mankind. Chicago: The University of Chicago Press.

Welch, A. R. (2001). Globalization, Post-modernity and the State: Comparative education for the third millenium. Comparative Education 37(4), 475-492.

Whitehead, C. (2003). Colonial Educators: The British Indian and Colonial Education Service 1858-1983. London: I. B. Tauris.

Whitehead, C. (2005). The historiography of British Imperial education policy. History of Education, 34(3), 315-329.

Wilkinson, R. (1964). The Prefects: British leadership and the public school tradition. Oxford: Oxford University Press. 